\title{
ОСОБЕННОСТИ ПРИВЛЕЧЕНИЯ ЛИЦА, ОСУЩЕСТВЛЯЮЩЕГО ФУНКЦИИ ЕДИНОЛИЧНОГО ИСПОЛНИТЕЛЬНОГО ОРГАНА, К СУБСИДИАРНОЙ ОТВЕТСТВЕННОСТИ ВНЕ ПРОЦЕДУРЫ БАНКРОТСТВА
}

\author{
(c) 2021 Гибадуллин Равиль Сагитович \\ аспирант кафедры правового обеспечения экономической деятельности \\ Самарский государственный экономический университет, Россия, Самара \\ E-mail: gib-rav@yandex.ru
}

\section{(c) 2021 Меденцева Евгения Владимировна}

кандидат юридических наук, доцент, заведующий кафедрой правового обеспечения экономической деятельности

Самарский государственный экономический университет, Россия, Самара

E-mail: medentsevae@mail.ru

Одной из новелл института субсидиарной ответственности при банкротстве, введенной в результате реформы 2017 г., стала возможность привлечения вне рамок дела о банкротстве контролирующих должника лиц к ответственности в случаях прекращения производства по делу о банкротстве ввиду недостаточности средств для покрытия расходов на проведение процедуры банкротства либо возвращения заявления о признании должника банкротом уполномоченному органу. В связи с этим арсенал средств привлечения руководителей юридических лиц к субсидиарной ответственности вновь пополнился.

Целью представленной работы является исследование особенностей привлечения контролирующих должника лиц к субсидиарной ответственности вне рамок дела о банкротстве, способствующее развитию доктринальных разработок по указанной проблематике и выработке новых предложений по усовершенствованию действующего законодательства. В частности, в работе анализируются нормы законодательства о банкротстве, определяющие круг лиц, обладающих правом на подачу заявления о привлечении к субсидиарной ответственности вне рамок дела о банкротстве. Делается вывод, что в этой части в законодательстве содержатся несколько противоречивые и двусмысленные положения. В связи с чем, в работе предложено внести изменения и дополнения в п. 3 и 4 ст. 61.14 Закона о банкротстве, устраняющие выявленные проблемы. Так, предлагается наделить кредиторов правом на подачу соответствующего заявления в случае прекращения производства по делу о банкротстве до введения процедуры наблюдения, а также устранить расхождения в определении круга лиц, имеющих право обратиться с заявлением о привлечении к субсидиарной ответственности, предусмотренные в п. 3 и 4 ст. 61.14 Закона о банкротстве.

Ключевые слова: субсидиарная ответственность; банкротство; контролирующее должника лищо; прекращение производства по делу о банкротстве; возвращение заявления о признании должника банкротом.

\section{ВВЕДЕНИЕ}

До изменений законодательства о банкротстве, произошедших в 2017 г., контролирующие должника лица (далее - КДЛ) активно использовали прекращение производства по делу о банкротстве на основании, предусмотренном абз. 8 п. 1 ст. 57 Федерального закона от 26.10.2002 № $127-Ф 3$ «О несостоятельности (банкротстве)» (далее - Закон о банкротстве), т.е. отсутствия у должника средств на финансирование проце- дуры, как инструмент, позволяющий избежать привлечения к субсидиарной ответственности, поскольку действующее на тот момент законодательство не предусматривало такой возможности вне рамок дела о банкротстве.

Схожие последствия возникали и в случае возвращения уполномоченному органу, который должен был доказать наличие у должника имущества, необходимого для финансирования процедуры*, заявления о признании должника

* Постановление Пленума ВАС РФ от 17.12.2009 № 91 «О порядке погашения расходов по делу о банкротстве» // Вестник ВАС РФ. 2010. № 2 . 
банкротом.

Отдельные попытки привлечения руководителей юридического лица к ответственности напрямую за причинение убытков кредиторам предпринимались в судах общей юрисдикции*. Однако положительные решения по такого рода делам носили скорее единичный характер, а заявителем выступал, как правило, уполномоченный орган (федеральная налоговая служба), возможность которого обратиться с подобным заявлением в суд общий юрисдикции была поддержана в своем время Верховным Судом Российской Федерации (далее - ВС РФ) [1, с. 58].

Вместе с тем, вектор развития современного законодательства о банкротстве становится все более «прокредиторским», а арсенал средств, направленных на восстановление нарушенных прав кредиторов, постоянно пополняется [2, с. 14]. Одной из новелл института субсидиарной ответственности, введенной в результате реформы 2017 г., стала возможность привлечения КДЛ к ответственности вне рамок дела о банкротстве за невозможность погашения требований кредиторов случаях прекращения производства по делу о банкротстве из-за отсутствия у должника средств на финансирование процедуры либо возврата заявления уполномоченного органа (подп. 1 п. 12 ст. 61.11 Закона о банкротстве).

При подобных же обстоятельствах привлечение КДЛ к субсидиарной ответственности стало возможно и по-другому банкротному основанию - за неподачу (несвоевременную подачу) заявления о банкротстве (ст. 61.12 Закона о банкротстве). Указанные нововведения требуют более пристального внимания и переосмысления, что предопределило актуальность представленной работы.

Стоит отметить, что в последние годы наблюдается увеличение дел, связанных с привлечением руководителей юридического лица к субсидиарной ответственности по долгам организации-банкрота. Так, по информации Судебного департамента при ВС РФ в 2020 г. было подано 5672 заявления о привлечении к субсидиарной ответственности. Из них арбитражные суды рассмотрели по существу 5109 заявления и удовлетворили 2997, что составляет почти 59\%. К слову, годом ранее было удовлетворено примерно такое же количество заявлений, но процент результативности вырос - в 2019 г. подано 5906 заявлений, удовлетворено 2995 , то есть $51 \%$ **.

Изучение судебной статистики позволяет обнаружить одну закономерность, имеющую непосредственное отношение к исследуемой теме. Интересно, что из 5672 поданных в 2020 г. заявлений о привлечении к субсидиарной ответственности 5482 были заявлены в рамках одной их процедур банкротства (5446 в отношении юридических лиц), т.е. вне процедуры банкротства подано только 190 заявлений, что составляет 3,3\% от общего количества заявлений.

Кроме того, в 2020 г. в арбитражные суды субъектов РФ поступило 34321 заявление о признании юридического лица банкротом, из них 6256 заявлений возвращено. Всего же в 2020 было рассмотрено 24736 дел о банкротстве юридических лиц, из которых 8878 дел прекращено на основании отсутствия средств, достаточных для возмещения судебных расходов (в рамках одной из процедур - 2009 дел). Т.е. 6869 дел прекращено на стадии проверки обоснованности заявления.

Получается, что на 24736 рассмотренных в отношении банкротства юридических лиц дел приходится 5446 заявлений о привлечении к субсидиарной ответственности, то есть в среднем на одно дело 0,22 заявления.

За рамками банкротства заявления могли подать заявители после возвращения заявления о признании должника банкротом или прекращения производства по абз.8 п.1 ст.57 Закона о банкротстве, т.е. на 6256 (возвращенных заявлений) + 8878 (прекращенных дел) приходится всего 190 заявлений, т.е. в среднем на одно «потенциальное» дело 0,0125 заявления.

Конечно подобные расчеты вряд ли могут

\footnotetext{
* См., например: Апелляционное определение Московского городского суда от 20.06.2016 № 33-23791/2016 // Судебные решения РФ: http://xn-90afdbaav0bd1afy6eub5d.xn - p1ai/41389122. Дата обращения: 26.05.2021 г.; Решение Нижегородского районного суда г. Нижний Новгород по делу № 2-9723/2012 от 29.10.2012 // Судебные решения РФ: http://xn-90afdbaav0bd1afy6eub5d.xn - p1ai/35107894. Дата обращения: 26.05.2021; Решение Оричевского районного суда Кировской области по делу № 2-94/2016 от 03.03.2016 г. // Судебные решения РФ: http://xn-90afdbaav0bd1afy6eub5d.xn - p1ai/12952744. Дата обращения: 26.05.2021 г.

** Отчет о работе арбитражных судов субъектов Российской Федерации по делам о банкротстве за 2020 г. // Судебный департамент при Верховном Суде Российской Федерации: http://www.cdep.ru/index.php?id=79\&item=5670. Дата обращения: 26.05.2021 г.
} 
отражать реальное положение дел, поскольку неизвестно точное количество возвращенных заявлений именно уполномоченному органу по рассматриваемому основанию. Но даже без учета возвращенных заявлений, на «прекращенные» дела в среднем приходится только 0,021 заявления. Более того, в расчете также не учитывалось количество дел, в которых конкурсное производство было завершено (7125 дел). Хотя лица, чьи требования не были удовлетворены в ходе конкурсного производства, после его завершения также обладают правом на подачу заявления о привлечении к субсидиарной ответственности за рамками банкротства (п. 1 ст. 61.19 Закона о банкротстве), т.е. полученная выше цифра с учетом подобных дел окажется еще меньше.

Приведенная статистика показывает, что вне процедуры банкротства с заявлением о привлечении к субсидиарной ответственности заинтересованные лица обращаются значительно реже. С одной стороны, это может указывать на потенциал указанного механизма и необходимость дальнейшего развития его использования, но с другой - на возможные проблемы, связанные с его реализацией. И в том, и другом случае привлечение к субсидиарной ответственности вне рамок дела о банкротстве требует более подробного рассмотрения.

Стоит признать, что в отечественной литературе проблемам субсидиарной ответственности КДЛ уделяется достаточно пристальное внимание. Огромный вклад в исследовании данной проблематики внесли О.В.Гутников [3-5] и И. С.Шиткина [6-8]. Также в последние годы по теме выпущено несколько монографий [9-11]

Вместе с тем, в указанных работах особенности привлечения к субсидиарной ответственности вне рамок дела о банкротстве детально не анализируются либо и вовсе упоминаются вскользь. Исследований, посвященных непосредственно рассматриваемому вопросу, встречается пока относительно немного, большинство из которых весьма поверхностные [12-14]. В некоторых заслуживающих внимание работах особенностям процедуры привлечения вне рамок дела о банкротстве уделено внимание лишь отчасти, большая же доля приходится на общие вопросы [15; 16]. В других - рассматриваются субъекты, привлекаемые к ответственности [17], что, как представляется, особенностей процедуры привлечения вне рамок дела о банкротстве не отражает, поскольку субъекты не отличаются от тех, что участвуют и в деле о банкротстве. Таким образом, можно констатировать, что обозначенная в работе тематика на сегодняшний день исследована в литературе недостаточно глубоко.

В этой связи цель представленной работы видится в исследовании особенностей привлечения КДЛ к субсидиарной ответственности вне рамок дела о банкротстве, способствующему развитию доктринальных разработок по указанной проблематике и выработке новых предложений по усовершенствованию действующего законодательства.

МЕТОДИКА ПРОВЕДЕНИЯ ИССЛЕДОВАния

В основу исследования лег метод юридического толкования, объектом которого выступили нормы главы III.2 Закона о банкротстве, поскольку одной из главных задач, поставленных в работе, было детальное изучение указанных положений и уяснение заложенного в их содержании смысла. При этом с помощью анализа и сопоставления были выявлены противоречия и юридико-технические недочеты в некоторых рассматриваемых нормах. Также анализу подверглись ключевые позиции высших судебных инстанций РФ по исследуемой тематике, благодаря чему удалось нивелировать часть противоречий. В результате синтеза выявленных недостатков были сформированы предложения, направленные на их устранение.

Кроме того, в работе использовались методы правовой статистики - статическое наблюдение и статистический анализ, позволившие определить актуальность выбранного направления исследования.

\section{РЕЗУЛЬТАТЫ ИССЛЕДОВАНИЙ}

1. Прекращение производства по делу о банкротстве из-за недостаточности средств для финансирования процедуры банкротства

В соответствии с действующим законодательством прекращение производства по делу о банкротстве по основанию, предусмотренному абз.8 п. 1 ст. 57 Закона о банкротстве, возможно, как на стадии проверки обоснованности заявления о признании должника банкротом, т.е. до введения наблюдения, так и после начала процедуры банкротства.

При этом в зависимости от этапа вынесения определения о прекращении производства по делу круг возможных заявителей о привлечении КДЛ к ответственности несколько отличается. В связи с этим представляется необходимым рас- 
смотреть подобный круг на каждом из указанных этапов.

\section{1. До введения наблюдения}

При буквальном прочтении положений п. 3 и 4 ст. 61.14 Закона о банкротстве, предусматривающих возможность обращения с заявлением о привлечении КДЛ к субсидиарной ответственности вне рамок дела о банкротстве, обнаруживается небольшое противоречие, на которое уже обращалось внимание в литературе [16, С. 51]. Дело в том, что такая возможность предусмотрена только по основанию, предусмотренному ст. 61.11 Закона о банкротстве, но, в то же время, по основанию, предусмотренному ст. 61.12 Закона о банкротстве, она прямо не установлена.

Вместе с тем, как представляется, развивать из этого проблему особо не стоит, поскольку ВС РФ уже исправил сложившееся недоразумение в Постановлении Пленума ВС РФ от 21.12.2017 № $53^{*}$ (далее - Постановление № 53), указав, что с требованием о привлечении к субсидиарной ответственности можно обратиться по любому из оснований, если «задолженность подтверждена вступившим в законную силу судебным актом или иным документом, подлежащим принудительному исполнению в силу закона». Хотя, как представляется, в целях гармонизации было бы уместно внести соответствующие правки и в текст самого законодательства.

Особо стоит отметить, что остальные лица, исходя из разъяснений ВС РФ, правом на подачу заявления в рассматриваемой ситуации не обладают. Компенсируются подобные ограничения, тем, что иные кредиторы могут присоединиться к поданному вне рамок дела о банкротстве заявлению (п. 52 Постановления № 53).

На заявителя возлагается обязанность по оповещению всех кредиторов о поданном заявление через размещение информации в ЕФРСБ или иным способом по требованию суда (п. 53 Постановления № 53)

Важно учесть, что заявление считается поданным в интересах всех кредиторов, независимо от того указаны они в заявлении или нет. Кредиторы могут присоединиться к поданному заявлению в любое время до вынесения судебного решения путем письменного обращения либо к заявителю, либо непосредственно в суд. В свою очередь заявитель должен проинформировать суд о присоединившихся лицах и несет ответственность перед ними в случае сокрытия такой информации (п. 54, 55 Постановления № 53 ).

Вместе с тем, указанные положения законодательства и позиция ВС РФ, не учитывают случай, когда заявитель по делу о банкротстве после прекращения производства по делу о банкротстве не станет обращаться с заявлением о привлечении КДЛ к субсидиарной ответственности. В такой ситуации иные кредиторы, не обладая правом на подачу соответствующего заявления, становятся ограниченными в возможностях на защиту своих прав по сравнению с заявителем, что не отвечает принципу равенства.

Видимо, для того, чтобы получить возможность обратиться с заявлением о привлечении КДЛ к субсидиарной ответственности, остальным кредиторам потребуется вновь обращаться с заявлением о признании должника банктором и вновь проходить процедуру прекращения производства по делу, что не соответствует принципам процессуальной экономии.

Кроме того, сама по себе возможность такого «второго круга» заявления о признании должника банкротом может вызывать сомнения в виду недопустимости повторного обращения в суд после прекращения производства по дела, установленной в п. 3 ст. 151 Арбитражного процессуального кодекса РФ. Однако, в качестве контраргумента можно указать, что в рассматриваемой норме сказано только о спорах «между теми же лицами». Формально иные кредиторы на данном этапе еще не являются участниками дела о банкротстве, поскольку такой статус возникает с момента принятия требования кредитора к рассмотрению судом (п. 30 Постановление Пленума ВАС РФ от 23.07.2009 № 60**).

Таким образом, кредиторы становятся перед выбором - либо ждать, когда заявитель по делу о банкротстве обратиться с заявлением о привлечении КДЛ к ответственности (хотя этого может и не случиться), либо, не дожидаясь решения заявителя, самостоятельно обратиться с заявлением о признании должника банкротом. При этом не совсем понятно, что должен делать

\footnotetext{
* Постановление Пленума Верховного Суда РФ от 21.12.2017 № 53 «О некоторых вопросах, связанных с привлечением контролирующих должника лиц к ответственности при банкротстве» // Российская газета. № 297. 29.12.2017.

** Постановление Пленума ВАС РФ от 23.07.2009 № 60 «О некоторых вопросах, связанных с принятием Федерального закона от 30.12.2008 № 296-ФЗ «О внесении изменений в Федеральный закон «О несостоятельности (банкротстве)» // Вестник ВАС РФ. 2009. № 9.
} 
суд, если одновременно будут поданы оба таких заявления.

Как представляется, решением указанной проблемы могло бы стать расширение круга лиц, обладающих правом на подачу заявления, включающее и остальных кредиторов, требования которых к должнику подтверждены вступившим в законную силу судебным актом или иным документом, подлежащим принудительному исполнению в силу закона.

Заявителю по делу о банкротстве, в свою очередь, необходимо предоставить возможность присоседиться к заявлению о привлечении к субсидиарной ответственности, поданному ранее другим кредитором, так, как это реализуется сейчас в контексте п. 52 Постановления № 53.

Кроме того, на кредитора, первым подавшего заявление о привлечении к субсидиарной ответственности, должны распространяться перечисленные выше обязанности по оповещению остальных кредиторов о поданном заявлении и информированию суда о присоединившихся лицах. Только при таком подходе устраняется неравенство в положении между всеми кредиторами.

\section{2. После начала процедуры банкротства}

Следующий рассматриваемый случай - прекращение производства по делу о банкротстве по основанию отсутствия финансирования, которое происходит в рамках одной из банкротных процедур. В этой ситуации круг возможных заявителей разнится в зависимости от основания для привлечения к ответственности.

Так, в соответствии с п. 3 ст. 61.14 Закона о банкротстве ими являются «кредиторы по текущим обязательствам, кредиторы, чьи требования были включены в реестр требований кредиторов, и кредиторы, чьи требования были признаны обоснованными, но подлежащими погашению после требований, включенных в реестр требований кредиторов». А согласно п. 4 ст. 61.14 Закона о банкротстве - «конкурсные кредиторы, а также работники должника, в том числе бывшие».

Некоторые расхождения в приведенных случаях вполне объяснимы, например, указания кредиторов по текущим обязательствам в круге лиц, предъявляющих требования по ст. 61.12 Закона о банкротстве, невозможно что называется «по определению», поскольку такие требования возникают после принятия заявления о признании должника банкротом.

Но расхождения в описании остальных субъ- ектах вызывают вопросы. В п. 3 ст. 61.14 Закона о банкротстве законодатель делит кредиторов на «реестровых» и «зареестровых», а в п. 4 ст. 61.14 Закона о банкротстве - на конкурсных кредиторов и работников. Как соотносить эти категории? Какой смысл законодатель заложил в эти различия? Требования работников должника что, не включаются в реестр? А «реестровые» и «зареестровые» кредиторы, они что, не конкурсные?

Чтобы ответить на поставленные вопросы, нужно учитывать следующее. Во-первых, согласно абз. 2 п. 6 ст. 16 Закона о банкротстве требования работников о выплате заработной платы и выходных пособий включаются в реестр требований кредиторов.

Во-вторых, как правило, под «зареестровыми» кредиторами понимают либо «опоздавших кредиторов», т.е. заявивших требования после закрытия реестра требований (п. 4 ст. 142 Закона о банкротстве), либо шире - кредиторов, чьи требования удовлетворяются после расчетов с кредиторами третьей очереди, т.е. в очередности, предшествующей распределению ликвидационной квоты.

K подобным требованиям помимо «опоздавших», в частности, можно отнести требования:

- по сделке, признанной недействительной по банкротным основаниям (абз. 5 п. 4 ст. 134 Закона о банкротстве);

- по субординированным облигациям (абз. 7 п. 4 ст. 134 Закона о банкротстве);

- руководителей должника по выплате выходного пособия и иных компенсаций сверх установленного законодательством размера (п. 2.1 ст. 134 Закона о банкротстве);

- кредиторов об осуществлении первоначального предоставления в части основного долга (п. 15 Обзора судебной практики Верховного Суда Российской Федерации № 1 за 2019 г. [18]);

- контролирующих должника и аффилированных с ним лиц [19].

При этом «опоздавшие кредиторы» прямо именуются в законе конкурсными (п. 4 ст. 142 Закона о банкротстве), а кредиторы по остальным указанным требованиям, с учетом разъяснений высших судов, обладают определенными процессуальными правами лица, участвующего в деле о банкротстве.

В этой связи, учитывая легальное определение конкурсного кредитора и перечень лиц, участвующих в деле о банкротстве (п. 1 ст. 34 Закона 
о банкротстве), есть основания считать «зареестровых» кредиторов конкурсными.

В таком случае, непонятно, намеревался ли законодатель подобными двусмысленными выражениями ограничить кого-то из указанных лиц в праве на подачу заявления о привлечении КДЛ к субсидиарной ответственности? Как представляется, все же нет.

Предоставление возможности на подачу заявления «зареестровым» кредиторам является еще одним проявлением «прокредиторского» вектора развития в законодательстве, на котором, видимо, законодатель хотел сделать акцент. Вместе с тем, очевидно, что, дав такую возможность в случае привлечения к ответственности по одному основанию, было бы не логично не предоставить ее и по другому. То же самое можно сказать и в отношении права, предоставленного работникам должника,- нет никакой логики в его ограничении в зависимости от основания привлечения к ответственности.

Именно поэтому в разъяснениях ВС РФ не проводится различий между кредиторами так, как это сделано в п. 3 и 4 ст. 61.14 Закона о банкротстве. Вместо этого ВС РФ использует обобщенные категории - «кредиторы и работники должника, чьи требования были признаны обоснованными и включены в реестр требований, в том числе в порядке п. 4 ст. 142 Закона о банкротстве» (п. 28. Постановления № 53 ).

В связи с этим, представляется необходимым устранить двусмысленные и бессодержательные расхождения в определении круга лиц, имеющих право обратиться с заявлением о привлечении КДЛ к субсидиарной ответственности, предусмотренные в п. 3 и 4 ст. 61.14 Закона о банкротстве, указав в п. 3 ст. 61.14 Закона о банкротстве, что подобным правом обладают кредиторы по текущим обязательствам, а также конкурсные кредиторы и работники (бывшие работники) должника.

2. Право уполномоченного органа обратиться с заявлением о привлечении КДЛ к субсидиарной ответственности

Уполномоченный орган, которым чаще всего выступает федеральная налоговая служба, традиционно является одним из наиболее активных участников в процедуре банкротства должника. Реализация публично-правовых функций и необходимость представлять интересы «казны» предопределяют безальтернативную обязанность уполномоченного органа обратиться с заявлением о признании должника банкротом.
В связи с чем уполномоченный орган обладает особым статусом в процедуре банкротства, существенно отличающимся от статуса кредиторов. При этом внедренные в ходе реформы 2017 г. правила о привлечении КДЛ к субсидиарной ответственности во многом упростили уполномоченному органу реализацию своих функций, добавив варианты возможных стратегий по взысканию задолженности за рамками дела о банкротстве.

\section{1. В случае возвращения заявления о при-} знании должника банкротом

Как уже отмечалось выше, уполномоченный орган при обращении с заявлением о признании должника банкротом должен доказать вероятность обнаружения у должника имущества, необходимого для покрытия расходов по делу о банкротстве, и в случае непредставления подобных доказательств заявление уполномоченного органа подлежит оставлению без движения с последующим возвращением (ст. 44 Закона о банкротстве).

В официальных разъяснениях ФНС России прямо указывается, что обращение с заявлением о банкротстве может происходить исключительно в целях получения определения о возврате заявления [20], поскольку после этого в соответствии с положениями п. 3 и 4 ст. 61.14 Закона о банкротстве уполномоченный орган вправе обратиться с заявлением о привлечении КДЛ к субсидиарной ответственности вне рамок дела о банкротстве.

При этом, в соответствии с разъяснениями ВС РФ иные лица подобными полномочия не наделяются (п. 30 Постановления № 53). Иными словами, право на обращение с заявлением о привлечении к субсидиарной ответственности при указанных обстоятельствах возникает только у уполномоченного органа.

Не совсем понятно, могут ли иные кредиторы присоединиться к поданному заявлению? Поскольку в разъяснениях ВС РФ не проводится различий между статусом заявителя, обратившегося с заявлением о привлечении к субсидиарной ответственности, можно сделать вывод, что уполномоченный орган также подает заявление в пользу всех кредиторов и наделяется обязанностью по их оповещению о поданном заявлении и информированию суда о присоединившихся лицах (п. 51-55 Постановления № 53). Однако, для устранения сомнений было бы правильным указать на это в разъяснениях ВС РФ.

Выше в работе в п. 1.1. рассматривалась схо- 
жая ситуация, и был сделал вывод о необходимости расширения круга возможных заявителей. В ситуации с возвращением заявления о признании должника банкротом уполномоченному органу, как представляется, подобной необходимости нет, поскольку указанная процедура несколько отличается от процедуры прекращения производства по делу о банкротстве.

В частности, обязанность предоставления доказательств вероятности обнаружения у должника имущества, необходимого для финансирования процедуры, установлена только у уполномоченного органа. В таком случае суд на стадии проверки обоснованности заявления о признании должника банкротом уже получает подтверждение наличия достаточного имущества, поэтому прекращение производства по делу о банкротстве на этой стадии просто невозможно.

2.2. В случае прекращение производства по делу о банкротстве из-за отсутствия у должника средств для финансирования процедуры банкротства

Вместе с тем, вполне мыслима ситуация, когда, даже несмотря на предоставленные доказательства вероятности обнаружения у должника имущества, недостаточность средств для финансирования может обнаружиться уже в ходе рассмотрения дела о банкротстве, в связи с чем производство по делу может быть прекращено. Кроме того, уполномоченный орган может вступить в дело о банкротстве и после начала процедуры банкротства и не предоставлять эти доказательства.

Обладает ли уполномоченный орган правом на подачу заявления о привлечении к субсидиарной ответственности в такой ситуации? Как ни странно, но ответ на этот вопрос не так-то прост.

При буквальном прочтении п. 3 ст. 61.14 Закона о банкротстве, получается, что уполномоченный орган наделен подобным правом только ... в случае возвращения заявления о признании должника банкротом. В остальных случаях, в частности, после прекращения производства по делу о банкротстве, упоминания о такой возможности в законе отсутствуют.

Однако, в п. 4 ст. 61.14 Закона о банкротстве уполномоченный орган уже фигурирует среди возможных заявителей. Чем обусловлено такое различие? Неужто законодатель решил не предоставлять ограничить уполномоченный орган в праве на подачу заявления? Как представля- ется, такое просто немыслимо, и дело все же в другом.

Выше уже упоминалась двусмысленность выражений, используемых в п. 3 ст. 61.14 Закона о банкротстве, видимо, и в рассматриваемом вопросе проблема кроется в ней же. По всей видимости законодатель посчитал, что уполномоченный орган в контексте п. 3 ст. 61.14 Закона о банкротстве вполне может быть отнесен к категории «кредиторов, чьи требования были включены в реестр требований кредиторов», а потому каких-либо дополнительных указаний не требуется. Но дело в том, что, поскольку уполномоченной орган не является кредитором с позиций гражданского правоотношения (не является участником обязательства), в терминологии Закона о банкротстве уполномоченный орган всегда противопоставляется кредиторам должника и наделяется особым правовым статусом. В этой связи не совсем понятна такая формулировка законодателя. Ничего другого, как списать это на юридико-техническую оплошность, просто не остается.

Таким образом, в дополнение к озвученным выше предложениям по уточнению круга лиц, имеющих право обратиться с заявлением о привлечении КДЛ к субсидиарной ответственности, уместно указать в п. 3 ст. 61.14 Закона о банкротстве, что подобным правом также обладает уполномоченный орган.

\section{ОСНОВНЫЕ РЕЗУЛЬТАТЫ}

В результате проведенного исследования было установлено, что действующее законодательство о банкротстве в части определения круга лиц, обладающих правом на подачу заявления о привлечении КДЛ к субсидиарной ответственности вне рамок дела о банкротстве в случае прекращение производства по делу о банкротстве из-за недостаточности средств для финансирования процедуры банкротства или возвращения заявления о признании должника банкротом уполномоченному органу, содержит несколько противоречивые и двусмысленные положения.

В связи с чем предложено внести изменения и дополнения в п. 3 и 4 ст. 61.14 Закона о банкротстве, устраняющие выявленные недостатки. В частности, предлагается:

- расширить круг лиц, обладающих правом на подачу соответствующего заявления в случае прекращения производства по делу о банкротстве до введения процедуры наблюдения, включив кредиторов, требования которых подтверж- 
дены вступившим в законную силу судебным актом или иным документом, подлежащим принудительному исполнению в силу закона;

- устранить двусмысленные расхождения в определении круга лиц, имеющих право обратиться с заявлением о привлечении КДЛ к субсидиарной ответственности, содержащиеся в п.
3 и 4 ст. 61.14 Закона о банкротстве, указав в п. 3 ст. 61.14 Закона о банкротстве, что подобным правом обладают кредиторы по текущим обязательствам, конкурсные кредиторы и работники (бывшие работники) должника, а также уполномоченный орган.

\section{Библиографический список}

1. Обзор судебной практики Верховного Суда Российской Федерации за четвертый квартал 2013 года (утв. Президиумом Верховного Суда РФ 04.06.2014) // Бюллетень Верховного Суда РФ. 2014. № 9.

2. Гибадуллин Р. С. Привлечение к субсидиарной ответственности контролирующих должника лиц при прекращении производства по делу о банкротстве либо возвращении заявления уполномоченного органа о признании должника банкротом // Актуальные проблемы развития правовой системы в цифровую эпоху: материалы II Международного юридического научного симпозиума (15 сентября 2020 г., Самара). Самара: Изд-во Самар. гос. экон. ун-та, 2020. С.13-16.

3. Гутников О.В. Корпоративная ответственность в гражданском праве. М.: Институт законодательства и сравнительного правоведения при Правительстве Российской Федерации, 2019. 488 с.

4. Гутников О.В. Субсидиарная ответственность за неисполнение обязанности подать заявление о банкротстве: новые правила // Хозяйство и право. 2018. № 2 (493). С. 92-108.

5. Гутников О.В. Ответственность контролирующих лиц по обязательствам ликвидированного юридического лица: pro et contra // Цивилистика. 2020. № 5. С. 214-246.

6. Шиткина И. С. Имущественная ответственность контролирующих должника лиц при банкротстве: очередные законодательные новеллы // Хозяйство и право. 2017. № 11 (490). С. 41-61.

7. Шиткина И.С. Ответственность контролирующих должника лиц при несостоятельности (банкротстве) // Хозяйство и право. 2017. № 8 (487). С. 3-24.

8. Шиткина И.С. Ответственность фактически контролирующих лиц в корпоративном праве // Закон. 2018. № 7. C. 114-133.

9. Лотфуллин Р.К. Субсидиарная и иная ответственность контролирующих должника лиц при банкротстве. [Электронное издание]. М.: Saveliev, Batanov \& Partners, 2021. 860 с.

10. Рыков И. Ю. Субсидиарная ответственность: тенденции современного менеджмента. 2-е изд. [Электронное издание]. М.: Статут, 2019. 195 с.

11. Суворов Е.Д. Субсидиарная ответственность по обязательствам несостоятельного должника. М.: Статут, 2020. 207 с.

12. Долгорукий А.И. Субсидиарная ответственность контролирующих лиц вне рамок дела о банкротстве // Евразийский юридический журнал. 2020. № 12 (151). С. 165-166.

13. Жукова Т. В. Привлечение к субсидиарной ответственности контролирующих должника лиц вне рамок дела о банкротстве // Молодой ученый. 2021. № 16 (358). С. 254-256.

14. Степанян E. К. Актуальные вопросы привлечения к субсидиарной ответственности контролирующих лиц вне рамок банкротного процесса // Тенденции развития науки и образования. 2021. № 69-4. С. 129-131.

15. Алтухов А.В., Левичев С.В. Процессуальные особенности рассмотрения заявлений о привлечении контролирующих должника лиц к субсидиарной ответственности при банкротстве // Судья. 2018. № 4. С. 27-32.

16. Светличный A.B. Субсидиарная ответственность контролирующих лиц вне рамок дела о банкротстве // Economics. Law. State. 2019. № 6 (8). C. 49-70.

17. Чечель В. М., Коваленко Т. С. Проблемы привлечения контролирующих должника лиц к субсидиарной ответственности вне рамок дела о банкротстве // Инновации. Наука. Образование. 2021. № 31. С. 619-626.

18. Обзор судебной практики Верховного Суда Российской Федерации № 1 (2019) (утв. Президиумом Верховного Суда РФ 24.04.2019) // Бюллетень Верховного Суда РФ. 2019. № 10.

19. Обзор судебной практики разрешения споров, связанных с установлением в процедурах банкротства требований контролирующих должника и аффилированных с ним лиц (утв. Президиумом Верховного Суда РФ 29.01.2020) // Бюллетень Верховного Суда РФ. 2020. № 7.

20. Письмо ФНС России от 16.08.2017 № СА-4-18/16148@ «О применении налоговыми органами положений главы III.2 Федерального закона от 26.10.2002 № 127-ФЗ» // Официальный сайт Федеральной налоговой службы: https://www.nalog.gov.ru/rn77/about_fts/docs/6968310/. Дата обращения: 26.05.2021 г. 